DOMINATED BY WOMEN: MANAGED BY MEN?

THE CAREER DEVELOPMENT PROCESS OF RETAIL MANAGERS

Adelina Broadbridge

Senior Lecturer

Department of Marketing

University of Stirling

STIRLING

FK9 4LA.

a.m.broadbridge@stir.ac.uk 


\section{DOMINATED BY WOMEN: MANAGED BY MEN? \\ THE CAREER DEVELOPMENT PROCESS OF RETAIL MANAGERS}

\section{Structured abstract}

Purpose: The aim of the paper is to explore some issues regarding the career

development of men and women retail managers and provide an overview of the main issues these present for retailers in the future.

Methodology/approach: The research utilised combination of quantitative and qualitative research methods. Data were collected via a questionnaire survey with 286 male and female UK retail managers.

Findings: Managers generally reported satisfaction with their current jobs and were highly ambitious to develop their careers. Factors managers particularly associated with facilitating their careers to date were attributed to own efforts and attitudes towards their work. Problems in their careers to date were associated with factors outside of their own control. The findings demonstrated that the culture of retailing is still perceived to be dominated by male norms and values and this has implications for the way in which men and women managers experience their jobs and career opportunities.

Practical implications: Managerial recommendations include the provision of meaningful mentoring relationships, the creation of developmental opportunities not bounded by a linear structure and re-examination of organisational cultural attitudes and practices. The importance of reconsideration of working arrangements and the 
provision of flexible working arrangements at all levels of the management hierarchy is emphasised.

Originality/value: The paper contributes to current understanding of the career issues experienced by UK retail managers in the $21^{\text {st }}$ Century.

Keywords: retail, managers, men, women, careeer development, working, employment 


\section{DOMINATED BY WOMEN: MANAGED BY MEN? THE CAREER DEVELOPMENT PROCESS OF RETAIL MANAGERS}

\section{Introduction and background to the study}

Retailing can be described as a highly feminised sector. Not only is its customer base highly feminised (Katz and Katz, 1997) but also so are its employees, with two thirds of them being women (Office for National Statistics, 2007). However, on closer inspection, it is clear that the positions that women employees occupy are highly segregated, and while they comprise the majority of front line service workers, they are disproportionately under represented in managerial positions, particularly senior positions. We might argue that this imbalance is economically (as well as morally) misguided and that by redressing the balance so this will result in the increased success of companies. First, we need some understanding of the career development processes experienced by male and female retail managers.

The data reported in this article come from a questionnaire survey conducted with a sample of UK retail managers. The questionnaire was sent to an alumni of MBA graduates, all of whom were retail managers. Each alumni member was sent seven questionnaires. One was for their own completion and in order to overcome potential selection bias based on one network source, they were asked to distribute a questionnaire each to another male and female junior, middle and senior manager in their organisation. In total 938 questionnaires were distributed and a total of 286 were returned providing a response rate of 30.49 per cent. An equal number of alumni and non alumni members returned questionnaires and therefore the results are not skewed 
toward those belonging to the alumni. Table 1 shows a demographic breakdown of the sample while Table 2 shows the job characteristics of the sample.

The study was designed to learn about various aspects of retail managers' careers (including satisfaction, working arrangements, career facilitators and problems encountered and future aspirations). Specifically, the objectives of the research were to:

- explore issues regarding the career development of men and women retail managers

- understand the factors that have facilitated retail managers' careers to date

- uncover the factors that have been problematic for retail managers in their careers to date

- explore issues relating to the gender balance of senior management positions

- identify managers' future career aspirations

- make recommendations to retail companies regarding the career development of their managers.

This paper reports some of the key findings from the research so as to provide a more comprehensive understanding of retail managers' careers in the $21^{\text {st }}$ century. It then highlights to retail companies some of the main issues facing retail managers today so that they can begin to respond to and address these concerns thus providing a positive career journey for the people that they employ.

$<$ Tables $1 \& 2$ about here $>$ 


\section{Retail managers' satisfaction with their current position}

Encouraging news was that most of the retail managers were satisfied with the various aspects of their current job (Table 3). Overall, three quarters of the respondents said that they were satisfied with their current job. Bearing in mind that relative deprivation theory has explained women's apparent 'satisfaction with less' (Jackson, 1989), when the various elements of their jobs were delineated there was little discernable differences between the men and the women's responses. The managers reported being particularly satisfied with their working relationships, their levels of responsibility, authority and autonomy, as well as their opportunities for involvement in challenging work situations. The less satisfying aspects of their jobs involved issues to do with career opportunities (international assignments, promotions, and opportunities to achieve their career aims including training opportunities) as well as concerns around organisational politics and recognition for their work achievements. Furthermore, in another part of the questionnaire, three quarters of the sample (76 per cent of men and 74 per cent of women) believed that their job was stressful (a similar finding to previous research [Broadbridge 1998a]), and over a third (35 per cent of men and 42 per cent of women) said that they found it difficult to unwind at the end of the day.

$<$ Table 3 about here $>$ 


\section{The factors that have facilitated retail managers' careers to date}

Based on previous research findings, Kirchmeyer (1998) identified four categories of phenomena which impact managerial careers: human capital (e.g. work experience, education), individual (personality traits, sex roles and motivation), interpersonal (mentors, support from superiors and networks) and family determinants (marriage, children, responsibilities).

Table 4 shows the relative importance respondents attributed to factors assisting their careers to date. The findings showed that there were several factors that both the men and women retail managers agreed have facilitated their careers the most. These relate to Kirchmeyer's categories of 'human capital' and 'individual' and all point to individuals' personality traits, motivation and work experience. These characteristics also corroborate with attribution theory (Heider, 1958). In addition, the women placed more emphasis than the men on their skill sets in facilitating their career development, although these findings were not statistically significant.

While the men and women shared opinions on the factors that had helped their careers to date, there were also some factors where men and women differed in their opinions. In particular, the women placed significantly more emphasis on various support mechanisms from within the organisation which relate to Kirchmeyer's 'interpersonal' category (support from a line/senior manager; attracting top level support; and network access). In contrast, the men placed significantly more emphasis on support from home or a partner which relates to Kirchmeyer's 'family determinants' category and mirrors the traditional roles expected by men and women. 
$<$ Table 4 about here $>$

\section{The main problems encountered by retail managers in their career to date}

When asked about the problems that the managers had encountered in their careers to date, the men and women managers again reported some similar problems (Table 5). The main problem mentioned by both the male and female managers was 'limited promotion opportunities'. In relation to Heider's attribution theory this is perhaps understandable as people are less likely to attribute their problems to factors within their own control or their own shortcomings. Nevertheless, the issue of limited promoted positions poses a very real problem for the sector as it is characterised by an apex hierarchical structure, and organisational re-structuring in recent years has witnessed a delayering of management positions. This has resulted in fewer management positions and levels to rise through to reach the top of the management hierarchy, thus creating a bottleneck effect for those aspiring to senior management positions. The present structure of organisations calls for a reappraisal of career developmental opportunities for retail managers.

$<$ Table 5 about here $>$

Of the other main problems reported, many of these relate to Kirchmeyer's 'interpersonal' category (organisational politics, absence of mentors, lack of feedback on performance, lack of career guidance, personality clashes and prejudice of colleagues). Interpersonal factors were further evidenced by the fact that many 
respondents believed that informal processes of selection existed in their organisations, that promotion is in the hands of one's line manager and that the old boy network is still prevalent in most organisations (Table 6). A few problems shared by the men and women related to Kirchmeyer's 'individual' category (lack of own career strategies, lack of confidence and personal factors).

Although the various problems encountered by the male and female managers were similar, there were some significant differences in the findings. These can broadly be related to Kirchmeyer's 'interpersonal' and 'human capital' categories. Women were significantly more likely to report problems of lack of training provision, lack of support from male colleagues, lack of role models, organisational attitudes towards women, the existence of a men's club network and sexual discrimination. Men, however, reported significantly more problems from their insufficient education (despite an equal proportion of the men and women having a university degree). While Kirchmeyer's four categories are useful in understanding the impact of managerial careers experienced by male and female retail managers, several problems highlighted by this research are largely related to the informal relations of an organisation and may be bound up with organisational cultural norms operating in retailing. It would seem that some of the factors broadly categorised under the 'interpersonal' category would be more usefully recategorised as 'organisational culture'.

Another part of the questionnaire provided respondents with a list of statements that have been found by prior research, and asked respondents to state to what extent they agreed or disagreed with the statements. These are shown in Table 6 and they lend 
support to some of the previous findings that facilitate or are problematic to retail managers and their career development. We shall return to some of the issues revealed by these data later in the paper.

$<$ Table 6 about here $>$

\section{Senior management positions in retailing}

Previous research has indicated the imbalance of women in senior management positions within retailing (Broadbridge, 1996; 1998b; Thomas, 2001; Singh and Vinnicombe, 2004; Maxwell and Ogden, 2006). It should be noted that the reason for the comparatively high level of women in senior positions in this research is owing to sampling techniques used. A strong business case can be made for ensuring that women are more equally represented in the senior and decision making positions of retail companies. Prior research has indicated the qualities that women bring to retail organisations such as strong interpersonal skills, a more caring, understanding manner and having more time for others (Brockbank and Traves, 1996). Therefore, we would expect that mixed work teams at all levels of the organisational hierarchy will understand a wider range of customer needs and help the organisation to become more profitable.

Respondents were asked if they considered there to be any possible effects on company performance of an under-representation of women at senior levels. Although some managers did not think there would be any effects (57 per cent of men and 31 per cent of women), in contrast, a feeling that there was an underutilisation of 
women's talents was reported by many respondents. In response to an open ended question, respondents indicated the lack of balance that exists within the senior management team if women are absent. They commented on the different approaches that men and women might have in their leadership and management styles, and the different perspective that women can bring to senior management positions. Women were felt to bring a more intuitive and sensitive perspective to management. Moreover, the evolving leadership styles in retailing are reflective of traditional female traits (teamwork, participative management styles, customer service). As a result, new business ideas can be generated from a more diverse senior management team.

Employing more women in senior management can also provide an improved corporate image for potential employees and customers. The respondents reported that a lack of women in senior management positions might pose a difficulty with regard to a lack of understanding of consumer issues, especially with there being a strong female customer base. Others (particularly the women) reported that women in senior management have a better understanding of female staff needs and can act as crucial role models for other aspiring women. This is important for the future attraction of women managers into the organisation.

Senior management was still considered to be a male preserve by both the men and women managers. The perceived barriers to women's advancement were attributed to five categories:

- family responsibilities (lack of child care facilities and family commitments) 
- the way work is organised (the long anti social hours of retailing and lack of flexi-time)

- organisational cultures (e.g. male dominance in the organisational hierarchy, outdated attitudes to women's roles and gender stereotyped beliefs)

- the invisibility of women at senior levels (a lack of female role models)

- women themselves (lack of confidence and lack of political awareness)

The constraints of work-home commitments were reported by around three quarters of the men and women, which on first inspection might appear to be unconnected with retailing per se. However, the way work is organised at senior levels in retailing does not appear to be sympathetic to managers' family responsibilities, and nothing is consequently being done to better accommodate family commitments by the working practices operating at senior levels. The issues concerned with the organisational culture of retailing and women's invisibility at senior levels were also important factors and reported by around half the sample. Women managers were significantly more likely than the men to state that women lacked confidence and political awareness to apply for senior positions. Their lack of confidence is perhaps unsurprising if they have few role models to aspire to and are used to being judged against male cultural norms and working practices. These findings suggest an organisational culture in retailing that is embedded in male values and ideology, alongside a reluctance to accommodate managers' familial roles. The male dominance in the organisational hierarchy, lack of female role models and outdated attitudes to women's roles pose significant difficulties in women breaking through the glass ceiling into senior management. Furthermore, some of the women and men stated that such company cultures and a reluctance to change were in themselves 
barriers to women achieving senior management positions in retailing (see Broadbridge (2008) for a more detailed examination).

\section{Future career aspirations of retail managers}

Most managers did not set out with a career life plan at the beginning of their careers; rather these have evolved over the course of their careers. Furthermore, around a quarter ( 21 per cent of men and 27 per cent of women) of the managers stated that they never have had a career plan. Nevertheless, as Table 6 demonstrates, the retail managers were highly ambitious to progress their careers, with the majority of men and women stating that they wanted to be considered for promotion - indicating a desire for linear progression (although issues of confidence might prevent some applying). Few managers indicated that they had already achieved their desired managerial position (11 per cent of men and 25 per cent of women). The majority of managers (61 per cent of men and 51 per cent of women) saw their next career move as being promoted either within their organisations ( 44 per cent of men and 41 per cent of women) or obtaining an external promotion (17 per cent of men and 10 per cent of women). Around a quarter indicated either a sideways career move (11 per cent of men and 12 per cent of women) or no change (13 per cent of men and 17 per cent of women), while a minority indicated retiral or a complete change of career ( 9 per cent of men and 9 per cent of women).

Where appropriate (i.e. discounting those already who had achieved these positions), almost half the men (47 per cent) and a quarter of the women ( 23 per cent) ultimately desired a director level position, and just over a third (36 per cent of men and 39 per 
cent of women) desired a senior management position. Moreover, around 80 per cent were optimistic that their goals would be met (42 per cent of men and 37 per cent of women think they are being very realistic and a further 40 per cent of men and 44 per cent of women are somewhat realistic about achieving their goals). The main strategies required to reach these positions were considered to be a continued effort to achieve strong results, gaining more experience and further training or qualifications. These mirror Kirchmeyer's 'individual' and 'human capital' categories. The potential barriers were the availability of the desired position and family commitments. Interestingly, Kirchmeyer's 'interpersonal' category was not mentioned as a help or a hindrance in achieving these positions despite earlier indications of the role this category plays in career development, and qualitative research that suggests this is important in the career development of retail managers (Broadbridge, 2004). Rather, upholding attribution theory (Heider, 1958), the strategies attributed to developing the managers' careers are located in themselves and the accumulation of human capital, while the potential barriers are connected with factors largely regarded as external to themselves and more to do with the organisation and its working practices.

\section{Discussion and implications for retail}

The findings from this research have highlighted that the pattern of career development for men and women retail managers has both similar and different features. Similarities existed between the men and women in terms of their levels of satisfaction with their current jobs; the factors they perceive have facilitated their careers and their ambitions for the future. Both men and women reported similarities in what has facilitated their careers (human capital and individual factors). Both have 
also suffered from similar problems in their careers to date (largely interpersonal factors). However, women also reported some differences from men in some factors facilitating (interpersonal) and hindering (interpersonal and human capital) their careers, while men were significantly more likely than women to perceive being helped by family determinants and hindered by human capital factors. Many of the differences were embedded in the corporate cultures and working practices experienced by the retail managers and these remained hurdles for many managers, especially women. Furthermore, family demands appear to work against career success, and family responsibilities not only were significantly more likely to fall on the women managers, but they were regarded by both the men and women retail managers as a key barrier for women progressing their careers to senior levels. Therefore, we might argue that explanations for the career development of retail managers can be derived from two broad positions: that of the organisation of employment itself and the sexual division of labour which places women's traditional roles within the family and men's within the workplace. With regard to retailing, these manifest themselves in the culture of retailing generally, and the working arrangements that impact on traditional roles expected of men and women in society.

\section{The culture of retail organisations}

Previous research has indicated that a masculine culture exists within in the retail sector (Marshall 1984; Cockburn 1991; Broadbridge 1998b). The findings of the current research suggest that the culture of retail organisations appears to still be entrenched in a patriarchal style which upholds various practices embedded in male based values and ideology. Corporate values often reflect the male stereotype and this 
was borne out by some of the responses of the retail managers. For example, one male director on explaining why there were relatively fewer women in senior positions than men stated:

'I think male domination. Even though we don't mean to, we're pretty biased and bigoted in our outlook' (male managing director, aged 42)

The findings generally suggest an absence of any overt discrimination within the sector (which supports Brockbank and Traves, 1996) which is encouraging and points to some progress; nonetheless not everyone considered that their organisation was committed to policies of equal opportunities (Table 6). Subtle negative attitudes or male cultural norms prevail and these make it difficult for women to progress on equal terms with their male counterparts. There still appears to be a viewed shared by some that a masculine culture exists in retailing and as such this will potentially benefit male retail managers more than women. (e.g. men are treated more favourably by management, advance more rapidly and are given better opportunities to network to assist their careers). Similar to the findings of Green et al (2004), it appears that women retail managers were significantly more likely than the men to hold the view that men do not like to be supervised by women, that women have to work much harder to prove themselves, that women still live and work in a man's world, and are under greater pressure at work than men.

As Green et al (2004) argued gender is still a major issue in the workplace because of the impact that gender stereotypes have on the attitudes and decision making of employers and employees alike. While the results of the current research revealed 
mixed findings in that many similarities existed between the reports of the male and female managers, it is clear that certain gendered cultural practices and beliefs still exist within the retail environment and beyond, and this is additionally signified by the relative lack of women in senior retail management positions. Halford and Leonard (2001) claimed that many men and women deny that gender plays a significant part in their experiences or career development. However, it is evident that in fact gender does play a substantial role in the way managers experience their working lives, albeit often subconsciously. As Green et al concluded gender issues were evident when women talked about their working lives but gender itself was not particularly revealed as a barrier. Similarly in the present study, although gender itself was rarely raised as a barrier, gender issues were apparent when comparing some of the findings between the men and women retail managers' responses to the questionnaire survey. They were even more noticeable when utilising qualitative research techniques where managers discussed at length their career development and opportunities (for further evidence of qualitative research in this context see Broadbridge 2004; 2007).

Working arrangements

Women's traditional role in the home environment is still dominant in the $21 \mathrm{st}$ Century despite the growth of dual career households, and research exists to show that women still contribute more to the domestic arena than men (Employment, Social Affairs \& Equal Opportunities, 2006; Eurostat, 2006), even in dual career households (Burke, 2002). Table 1 also shows that women retail managers were no exception: they reported being significantly more likely to take responsibility for home and 
caring duties while, for some, their career takes a secondary position to that of their partners'.

Retailing is renowned for long working hours at managerial levels and prior research found this to be between 50 and 90 hours per week (Broadbridge, 2002). The questionnaire results revealed that the men reported on average working longer hours per week (50.04 hours) than the women (45.45). However, a quarter of the men and women also reported taking work home with them in the evenings (Table 2). Further investigation showed that the higher the management position occupied, the longer the hours reported working was. So for example, directors reported working the longest hours with three quarters ( 72 per cent) stating they worked over 50 hours per week. Two thirds (64 per cent) of the senior managers worked beyond a 50 hour week against 38 per cent of middle managers and 17 per cent of junior managers. This is tantamount to the long hours culture that has traditionally been characteristic of the retail trade and it would appear this is additionally reinforced by the position occupied in the managerial hierarchy. This presents difficulties for those with additional non-work commitments (and typically, as Table 1 suggests, women) as they attempt to juggle both domains and undertake the 'second shift' (Hothschild, 1989). In practice, many women are forced to sacrifice one domain for the other: they either postpone or forego starting a family in order to pursue their careers (as might be the case of many of the women in this survey [Table 1]); else their career potentially suffers or halts in their pursuit of family activities. Another position is that some women are outsourcing their domestic responsibilities (typically to other women) in order that they can pursue their careers in addition to raising a family. 
In an effort to maintain their staff costs, retailers have long since employed flexible working arrangements at non-managerial levels through the utilisation of sophisticated computerised scheduling arrangements. However, the operation of flexible working arrangements relied upon so heavily at non-managerial levels is not employed to the same extent in managerial positions. This is ironic as in nonmanagerial positions the very flexibility of working arrangements is what helps many employees (including women, older people and students) combine their work and non-work domains, and makes retail an attractive career option. The more senior the position within the retail hierarchy, the less flexibility there appears to exist and the more difficult it is to balance work and non-work commitments. Yet, the research showed that both men and women retail managers would welcome more flexible working arrangements (Table 2). Moreover, over a third of the managers believed that flexible work arrangements were possible for managerial careers in retailing. Even the managers in senior positions considered that their jobs could be performed on a more flexible basis, with around a third believing most aspects of their job could be carried out on a more flexible basis and three quarters saying at least some aspects could be performed more flexibly than they currently are (See Broadbridge, 2008 for further details).

\section{Managerial recommendations}

The recommendations to be drawn from the findings of this survey can be applied to employees and employers. From an employee perspective, it is important to recognise the importance of having individual and human capital credentials, together with a positive attitude of mind. However, individual managers also need to be aware 
that additional factors matter in their career development, and so they also need to recognise the importance of other people's opinions and the power of interpersonal factors. Various managers in this survey recognised the positive or negative influence that interpersonal factors might play in their career development. At an organisational level, the provision of stimulating and effective mentorships would be one way to assist the career development of managers. The benefits of mentoring for career development purposes are well documented (e.g. Kram, 1985; Clutterbuck, 1991; Wright and Werhter, 1991; Chao, 1997; Broadbridge, 1999). In career development terms, mentors can offer career advice and counselling, sponsorship and provision of opportunities. The relationship can lead to exposure to more senior management levels, and provide a better understanding of the formal and informal structure of the organisation. Through mentoring the mentees develop their abilities and skills and gain in self awareness and confidence. All of these benefits can positively affect career development and would address many of the issues that have arisen in this research. These relationships do not have to be on site; there is an increasing use of ementors (Headlam-Wells et al, 2006; Hunt et al, 2007) and these types of relationships might be ideally suited to the spatially diverse retail environment.

One of the main drawbacks to career development reported by the retail managers was the limited promotional opportunities. This is a reflection of the restructuring that has occurred within the retail environment in response to competitive pressures. It is unlikely that this situation will reverse and, therefore, this calls for retail organisations to be more creative in the developmental opportunities that they provide for their managers. These can draw on the factors that particularly satisfy managers who reported enjoying work that gives them a sense of challenge, autonomy and 
responsibility. In recognition that times are changing, so retailers need to create developmental opportunities that are not bound by a linear structure. Rather, they need to be cognisant of other ways of developing staff in order to retain them and consider and embrace, for example, the growth of what Baruch (2004) terms multidirectional career systems. Although many epitomise career success in terms of linear progression, men and women are also beginning to frame their careers more broadly and less traditionally than in the past (Greenhaus at al, 2000). The notion of the protean career (where the individual takes charge of their own career) which addresses whole life concerns and is not based solely on advancement has developed in recent years (Hall and Mirvis, 1996). By endorsing career structures characterised by lateral and multi directional movements (in addition to linear ones) companies can provide a wider, rounder, richer career developmental experience for their employees. Of course, this requires a simultaneous review of reward structures to take due recognition of these developing career structures. The way retail companies are structured, however, means they are ideally placed to provide these meaningful career opportunities and challenges. If they combine these opportunities with meaningful mentoring relationships that empower individuals to take charge of their own careers, and understand that their career development (and rewards structures) can take many forms, this potentially has long term benefits for the health of organisations and employees alike.

Moreover, the emergence of a workforce dominated by Generation Y employees (those born between 1977 and 1994), means retail companies also need to ensure that the future developmental opportunities they provide their employees incorporate the characteristics and demands of this generation. This generation has been shown to 
have different expectations from their work role than older employees including the desire for a more balanced lifestyle between their work and non-work lives (Anon, 2006). One way of achieving this more balanced lifestyle is via offering employment flexibility (Kerslake, 2005). Generation Y also desire careers that provide training and want to work for companies with positive company cultures that embrace diversity, equality and tolerance (Morton, 2002). Therefore, proactive retail companies should be seriously re-examining their cultural norms and present working arrangements at managerial levels now in an effort to both meet the career development needs of their current workforce and to incorporate the demands of the growing Generation Y employees.

Another recommendation for retail organisations, then, is to re-examine cultural attitudes and uncover the reasons why, despite there being various similarities in career experiences to date and little differences in career aspirations of retail managers, there remains an imbalance of men and women at the top of retail organisations. This might begin with employers examining carefully their basic assumptions about women in management. Previous research has shown that male managers are unaware of certain barriers women face in their career development (BITC/Conference Board, 2000) and that men may be reporting a sense of 'change for the better' for women's career advancement, while women report 'continuing discrimination and stereotyping' (Vinnicombe and Singh, 2002). There may be some evidence to support these assertions from the current research - many men it would appear still hold stereotypes and preconceptions about women's roles and abilities (Table 6). They need to be educated to the issues women face so that they can embrace the more positive cultures demanded by Generation Y. 
Retail organisations must reconsider working arrangements at all levels of the managerial hierarchy. The very way work is organised at managerial levels makes it difficult to combine employment with other responsibilities. Yet, the findings of the research suggest that it is not an inability for there to be more flexible arrangements at managerial (including senior) levels as men and women alike agree at least some of the their roles can be performed on a more flexible basis. Therefore to remain competitive and to attract and retain good quality managers, retail companies need to revise their working practices at managerial levels so as to better accommodate many female and male managers' lives. They need to recognise that a better work-life balance will benefit all employees, not just women. The answer to what is preventing more flexible working arrangements being offered at senior positions must be considered. This involves not just looking at the way work is organised but also involves a critical appraisal of the underlying systems that uphold these working structures. Otherwise a management structure that maintains senior positions for a select few who are willing and able to accommodate current working practices will be perpetuated. This is not only potentially detrimental to both many men and women managers, but also has wider implications for the effective running of retail organisations.

\section{Conclusion and future research agenda}

This study has built on previous literature on the career development of retail managers. Using a questionnaire survey the findings revealed that similarities and differences exist in male and female retail managers' career development. Relating 
the findings back to Kirchmeyer's phenomena, both men and women associate individual characteristics and human capital phenomena to facilitating their careers and interpersonal phenomena as being problematic to their careers. Some differences were also observed: most notably with women reporting both benefiting from and enduring interpersonal phenomena and men acknowledging the support of family determinants in facilitating their careers and their lack of human capital (education) as problems. Moreover, the research revealed that women were not achieving parity in senior management positions in retailing. Reasons for this can be located in the cultural norms that prevail in the retail environment and the organisation of employment.

In conclusion, the study has raised various issues in the career development of retail managers that can be extended by future research. Further research into the facilitators and inhibitors is warranted, and it would be useful to delineate the findings by managerial level in order to establish the relative importance of various factors for career developmental purposes at certain stages of career. Given the relative interplay of Kirchmeyer's phenomena found in the current research, further research looking at the contribution of individual and interpersonal factors (including formal and informal policies and practices within retail organisations) to career development is necessary. Furthermore, the issue of flexible working arrangements and home responsibilities needs to be further unpicked so as to gain a better understanding to what extent these are barriers for both men and women. With the recognition of different career structures and the emergence of Generation $\mathrm{Y}$ and the relative importance they attach to whole life concerns, further research with this generation of employees is needed in 
order that feasible recommendations can be made to retail employers for the best ways of matching this generation's needs. 


\section{References}

Anon (2006) 'Y Bother?', Accountancy Magazine.com, May :131.

Baruch, Y. (2004) 'Transforming Careers: From Linear to Multidirectional Career Paths: Organizational and Individual Perspectives, Career Development International, 9(1):58-73

BITC/Catalyst (2000) Breaking the Barriers: Women in Senior Management in the UK. London: Business in the Community, Opportunity Now and NY: Catalyst.

Broadbridge, A. (1996) 'Female and Male Managers - Equal Progression?' International Review of Retail, Distribution and Consumer Research, 6 (3): 255-270.

Broadbridge, A. (1998a) Stress in Retailing: Preliminary Analysis of the Experiences of Retail Managers, IRS Working Paper no 9803, Institute for Retail Studies, University of Stirling

Broadbridge, A. (1998b). 'Barriers in the Career Progression of Retail Managers' International Review of Retail, Distribution and Consumer Research, 8(1), 1-26.

Broadbridge, A. (1999) 'Mentoring in Retailing: A Tool for Success?' Personnel Review, 28 (4): 336-355.

Broadbridge, A. (2002) 'Retail Managers: Their Work Stressors and Coping Strategies' Journal of Retailing and Consumer Services, 9 (3):173-183.

Broadbridge, A. (2004) 'It's Not What You Know But Who You Know' Journal of Management Development, 23 (6): 551-562.

Broadbridge, A. (2007) 'The Relevance of Human Capital and Social Capital Theory in Explaining Ascension to Senior Management Roles', British Academy of Management Annual Conference, Warwick, September 13-15 2007.

Broadbridge, A. (2008) 'Barriers to Ascension to Senior Management Positions in Retailing', Services Industries Journal, 28 (9): November, forthcoming.

Brockbank, A. and Traves, J. (1996) 'Career Aspirations - /women Managers in Retailing', in Ledwith, S. and Colgan, F. (Eds.) Women in Organisations: Challenging Gender Politics. London: Macmillan.

Burke, R. (2002) 'Career Development of Managerial Women', in Burke, R.J. and Nelson, D.L. Advancing Women's Careers. Oxford: Blackwell Publishers.

Chao, G. (1997) 'Mentoring Phases and Outcomes', Journal of Vocational Behavior, . 51: $15-28$.

Clutterbuck, D. (1991) Everyone Needs A Mentor: Fostering Talent at Work, Second Edition. Institute of Personnel Management, London. 
Cockburn, C. (1991) In the Way of Women: Men's Resistance to Sex Equality in Organizations. London: Macmillan.

Employment, Social Affairs \& Equal Opportunities (2006) Women and men in decision making. A question of balance. EUROPA.

Eurostat (2006) 'A Statistical View of the Life of Women and Men in the EU25' News Release, 29/2006 6 March 2006

Green, E.; Moore, J.; Easton, H. and Heggie, J. (2004) Barriers to Women's Employment and Progression in the Labour Market in the North East of England. Research Report February 2004, Centre for Social and Policy Research, University of Teesside.

Greenhaus, J.H., Callanan, G.A. and Godshalk, V.M. (2000) Career Management, Third Edition, Thompson-South-Western, Mason, $\mathrm{OH}$.

Halford, S. and Leonard, P. (2001) Gender, Power and Organisations. Basingstoke: Palgrave.

Hall, D.T. and Mirvis, P.H. (1996) 'The New Protean Career: Psychological Success and the Path with a Heart', in Hall, D.T. The Career is Dead - Long Live the Career. San Francisco: Jossey-Bass Publishing.

Headlam-Wells, J., Craig, J. and Gosland, J. (2006) 'Encounters in Social Cyberspace: E-Mentoring for Professional Women', Women in Management Review, 21(6): 483-99.

Heider, F. (1958). The Psychology of Interpersonal Relations. New York, John Wiley \& Sons.

Hothschild, A. (1989) The Second Shift. New York: Avon.

Hunt, C., Fielden, S.L., Dawe, A.J. and Davidson, M.J. (2007) 'A Longitudinal Study Designed to Examine the Effectiveness of and E-Coaching Programme for Female Entrepreneurs in the North West of England', EURAM Annual Conference, Paris, May 17- 19.

Jackson, L.A. (1989) 'Relative deprivation and the gender wage gap', Journal of Social Issues, 45 (4): 117-133.

Katz, P. and Katz, M. (1997) The Feminist Dollar. New York: Plenum.

Kelley, H.H. (1973). 'The Process of Casual Attribution', American Psychologist, February, 107-128.

Kerslake, P. (2005) 'Words From the Ys', Management, May: 44-46.

Kirchmeyer, C. (1998) 'Determinants of Managerial Career Success: Evidence and Explanation of Male/Female Differences', Journal of Management, 24(6):673-92. 
Kram, K. (1985) Mentoring at Work: Developmental Relationships in Organizational Life, University Press of America, Lanham, Maryland.

Marshall, J. (1984) Women Managers - Travelers in a Male World. Chichester: Wiley.

Maxwell G. and Ogden S. (2006) 'Career development of female managers in retailing: Inhibitors and enablers,' Journal of Retailing and Consumer Services, Vol. 13, pp111-120.

Morton, L.P. (2002) 'Targeting Generation Y', Public Relations Quarterly, Summer: 46-48.

Office for National Statistics (2007) Economic and Labour Market Review, 1(4):

Table 6.05, London: HMSO, April..

Singh, V. and Vinnicombe, S. (2004). The 2004 Female FTSE Report 2004.

Cranfield School of Management: Cranfield, December.

Thomas, A. (2001) 'Women at the Top of British Retailing: A Longitudinal Analysis', The Service Industries Journal, 21(3): 1-12.

Vinnicombe, S. and Singh, V. (2002). 'Sex Role Stereotyping and Requisites of Successful Top Managers', Women in Management Review, 17(3/4), 120-30.

Wright, R. G. and Werther, W. B. Jr., (1991) 'Mentors at Work', The Journal of Management Development, 10(3): 25-32. 
Table 1: Demographic Characteristics of the Retail Management Sample

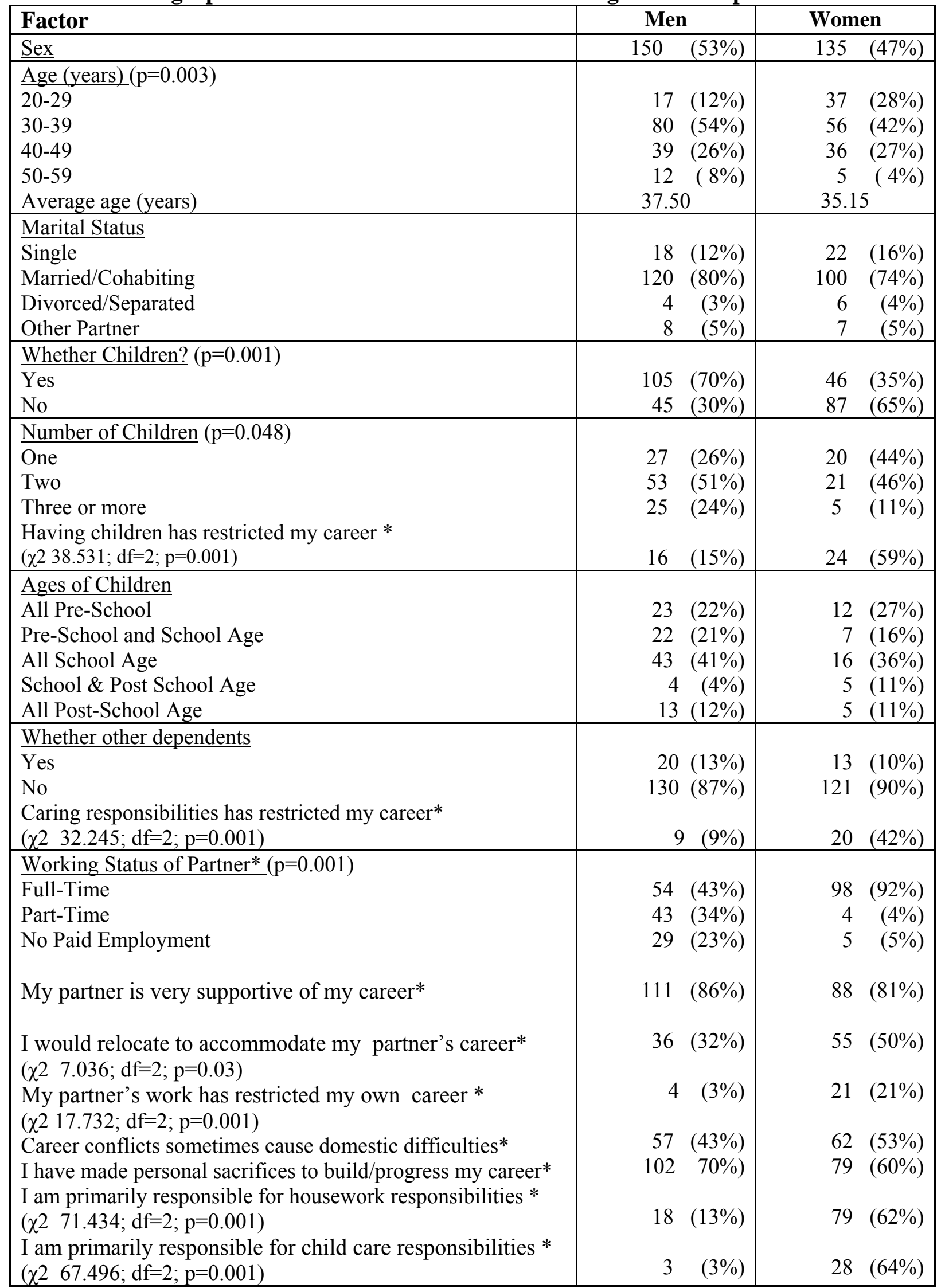

* (\% agreeing, where appropriate) 
Table 2: Work and Educational Experiences of Retail Management Sample

\begin{tabular}{|c|c|c|}
\hline Factor & Men & Women \\
\hline Total years of work experience (average) $(\mathrm{p}=0.01)$ & 18.84 & 15.72 \\
\hline Total years of managerial experience (average) $(\mathrm{p}=0.01$ ) & 12.53 & 8.58 \\
\hline Years with present employer & 10.02 & 7.74 \\
\hline Years in present position & 3.04 & 2.72 \\
\hline Number of companies worked for & 3.36 & 3.36 \\
\hline $\begin{array}{l}\text { Management Level* }(p=0.001) \\
\text { Junior } \\
\text { Middle } \\
\text { Senior } \\
\text { Director } \\
\text { Other (e.g. trainee) }\end{array}$ & $\begin{array}{rr}16 & (11 \%) \\
59 & (39 \%) \\
55 & (37 \%) \\
19 & (13 \%) \\
1 & (0.7 \%)\end{array}$ & $\begin{array}{rr}28 & (21 \%) \\
46 & (34 \%) \\
44 & (33 \%) \\
6 & (4 \%) \\
11 & (8 \%)\end{array}$ \\
\hline $\begin{array}{l}\text { Job Location }(\mathrm{p}=0.001) \\
\text { Store } \\
\text { Head office, distribution } \\
\text { Area/ Field Management }\end{array}$ & $\begin{array}{ll}41 & (29 \%) \\
85 & (59 \%) \\
18 & (13 \%)\end{array}$ & $\begin{array}{l}(20 \%) \\
(77 \%) \\
3(2 \%)\end{array}$ \\
\hline $\begin{array}{l}\text { Job Function }(\mathrm{p}=0.001) \\
\text { Functional Specialist } \\
\text { Generalist }\end{array}$ & $\begin{array}{ll}58 & (40 \%) \\
89 & (61 \%)\end{array}$ & $\begin{array}{ll}70 & (54 \%) \\
60 & (46 \%) \\
\end{array}$ \\
\hline $\begin{array}{l}\text { Number of Companies Worked For } \\
\text { One } \\
\text { Two } \\
\text { Three } \\
\text { Four or more } \\
\text { Average (number) }\end{array}$ & $\begin{array}{ll}30 & (20 \%) \\
35 & (24 \%) \\
28 & (19 \%) \\
56 & (38 \%) \\
3.36\end{array}$ & $\begin{array}{ll}21 & (16 \%) \\
32 & (24 \%) \\
28 & (21 \%) \\
53 & (40 \%) \\
3.36 & \end{array}$ \\
\hline $\begin{array}{l}\text { Hours Worked }(\mathrm{p}=0.001) \\
13-39 \text { hours } \\
40-49 \text { hours } \\
50-59 \text { hours } \\
60-70 \text { hours } \\
\text { Average hours worked per week } \\
\% \text { full time } \\
\text { I take work home most evenings* } \\
\text { I like working long hours* } \\
\text { Work takes precedence over non-work life* } \\
\text { I would welcome more flexible working arrangements* } \\
(\chi 212.833 ; \text { df }=2 ; p=0.002) \\
\text { Flexible work arrangements are possible } \\
\text { for managerial careers in retailing* }\end{array}$ & $\begin{array}{cc}15 & (11 \%) \\
43 & (31 \%) \\
48 & (34 \%) \\
34 & (24 \%) \\
& 50.04 \\
& 100 \% \\
35 & (24 \%) \\
20 & (13 \%) \\
64 & (43 \%) \\
62 & (42 \%) \\
& \\
53 & (36 \%)\end{array}$ & $\begin{array}{rr}32 & (24 \%) \\
57 & (43 \%) \\
26 & (20 \%) \\
18 & (14 \%) \\
& 45.45 \\
& 96 \% \\
33 & (25 \%) \\
14 & (11 \%) \\
49 & (36 \%) \\
84 & (64 \%) \\
& \\
49 & (37 \%)\end{array}$ \\
\hline $\begin{array}{l}\text { Educational Attainment* }(\mathrm{p}=0.08) \\
\text { None } \\
\text { GCSE/ O'Level } \\
\text { A Level or Equivalent } \\
\text { First Degree } \\
\text { Post-Graduate Diploma } \\
\text { Higher Degree }\end{array}$ & \begin{tabular}{rr|}
4 & $(3 \%)$ \\
21 & $(14 \%)$ \\
34 & $(23 \%)$ \\
35 & $(24 \%)$ \\
17 & $(11 \%)$ \\
37 & $(25 \%)$ \\
\end{tabular} & $\begin{array}{rr}2 & (2 \%) \\
15 & (11 \%) \\
36 & (27 \%) \\
38 & (28 \%) \\
26 & (19 \%) \\
16 & (12 \%) \\
\end{array}$ \\
\hline $\begin{array}{l}\text { Have Additional Professional Qualification } \\
\text { Yes }\end{array}$ & $(37 \%)$ & $(38 \%)$ \\
\hline
\end{tabular}

* (\% agreeing with statement $)$ 
Table 3 : Satisfaction with various aspects of managers' current jobs

\begin{tabular}{|c|c|c|}
\hline Factor & Men & Women \\
\hline I am satisfied with my current job & $112 \quad(75 \%)$ & $96 \quad(72 \%)$ \\
\hline Working relationship with colleagues & $138 \quad(92 \%)$ & $(91 \%)$ \\
\hline Credibility with staff & $137 \quad(91 \%)$ & $121 \quad(90 \%)$ \\
\hline Working relationship with subordinates & $130 \quad(87 \%)$ & $(90 \%)$ \\
\hline The degree of responsibility you have & $129 \quad(86 \%)$ & $(82 \%)$ \\
\hline Credibility with line managers & $133(89 \%)$ & $(81 \%)$ \\
\hline Working relationship with superiors & $119 \quad(79 \%)$ & $106 \quad(79 \%)$ \\
\hline $\begin{array}{l}\text { The degree of job security they have } \\
\left(\chi^{2} 9.174 ; \mathrm{df}=2 ; \mathrm{p}=0.01\right)\end{array}$ & $96 \quad(64 \%)$ & $105(78 \%)$ \\
\hline $\begin{array}{l}\text { Opportunities for involvement in challenging work } \\
\text { situations }\end{array}$ & $116 \quad(78 \%)$ & $103(76 \%)$ \\
\hline Your level of autonomy/ independence & $115(77 \%)$ & $(76 \%)$ \\
\hline $\begin{array}{l}\text { Job location } \\
(\chi 2 \text { 6.273; } \mathrm{df}=2 ; \mathrm{p}=0.043)\end{array}$ & $110 \quad(73 \%)$ & $103(76 \%)$ \\
\hline $\begin{array}{l}\text { Support from immediate seniors } \\
\left(\chi^{2} 6.748 ; \mathrm{df}=2 ; \mathrm{p}=0.034\right)\end{array}$ & $93 \quad(62 \%)$ & $(71 \%)$ \\
\hline Level of authority delegated to you & $121 \quad(81 \%)$ & $94 \quad(70 \%)$ \\
\hline Status /prestige & $97 \quad(65 \%)$ & $(70 \%)$ \\
\hline Conditions of work & $102(68 \%)$ & $91 \quad(67 \%)$ \\
\hline The calibre of the work allocated to you & $112 \quad(75 \%)$ & $(66 \%)$ \\
\hline Opportunities for self development & $102 \quad(68 \%)$ & $(64 \%)$ \\
\hline Total hours of work & $74 \quad(49 \%)$ & $(61 \%)$ \\
\hline Salary & $84 \quad(56 \%)$ & $(59 \%)$ \\
\hline Opportunities to achieve career aims & $(55 \%)$ & $(55 \%)$ \\
\hline The level of training received & $77 \quad(51 \%)$ & $(54 \%)$ \\
\hline Recognition for work achievement & $71 \quad(47 \%)$ & $(50 \%)$ \\
\hline Opportunities to influence organisational politics & $(58 \%)$ & $(48 \%)$ \\
\hline Opportunities for promotion & $67 \quad(45 \%)$ & $(45 \%)$ \\
\hline Opportunities for international assignments & $48 \quad(32 \%)$ & $(30 \%)$ \\
\hline
\end{tabular}


Table 4: Factors assisting managers careers to date (those stating a great deal or quite a lot)

\begin{tabular}{|c|c|c|}
\hline Factor & Men & Women \\
\hline Attitude to work & $139 \quad(93 \%)$ & $123 \quad(93 \%)$ \\
\hline Determination & $(87 \%)$ & $117 \quad(87 \%)$ \\
\hline Interpersonal skills & $(78 \%)$ & $116(88 \%)$ \\
\hline Concern for results & $(84 \%)$ & $110 \quad(83 \%)$ \\
\hline Breadth of experience & $129 \quad(87 \%)$ & $107 \quad(82 \%)$ \\
\hline Past and present performance & $121 \quad(81 \%)$ & $108 \quad(81 \%)$ \\
\hline Relevant skills & $(72 \%)$ & $106 \quad(80 \%)$ \\
\hline Being offered challenging work & $106 \quad(72 \%)$ & $100 \quad(76 \%)$ \\
\hline Support from a line/senior manager $\left(\chi^{2} 6.271 ; \mathrm{df}=2 ; \mathrm{p}=0.043\right)$ & $(61 \%)$ & $98 \quad(75 \%)$ \\
\hline Ambition & $(74 \%)$ & $97 \quad(74 \%)$ \\
\hline Demonstrating critical skills for effective job performance & $108 \quad(73 \%)$ & $92 \quad(71 \%)$ \\
\hline Being accepted by the organisation & $(62 \%)$ & $92 \quad(71 \%)$ \\
\hline Assistance or coaching by others & $(66 \%)$ & $(69 \%)$ \\
\hline Being offered visible assignments & $83 \quad(57 \%)$ & $87 \quad(67 \%)$ \\
\hline Being valued & $(60 \%)$ & $87 \quad(66 \%)$ \\
\hline Receiving support and encouragement & $(57 \%)$ & $86 \quad(66 \%)$ \\
\hline Certain job moves & $84 \quad(58 \%)$ & $82 \quad(64 \%)$ \\
\hline Loyalty & $98 \quad(66 \%)$ & $82 \quad(63 \%)$ \\
\hline Attracting top level support & $67 \quad(46 \%)$ & $80 \quad(63 \%)$ \\
\hline Self esteem & $(60 \%)$ & $81 \quad(62 \%)$ \\
\hline High visibility & $(55 \%)$ & $81 \quad(61 \%)$ \\
\hline Access to high profile/challenging assignments & $71 \quad(50 \%)$ & $77 \quad(61 \%)$ \\
\hline Willingness to be mobile & $87 \quad(61 \%)$ & $65 \quad(55 \%)$ \\
\hline Broadening general management experience & $91 \quad(62 \%)$ & $68 \quad 54 \%)$ \\
\hline Training & $75 \quad(50 \%)$ & $70 \quad(53 \%)$ \\
\hline $\begin{array}{l}\text { Support from home or partner } \\
(\chi 210.307 ; \mathrm{df}=2 ; \mathrm{p}=0.006)\end{array}$ & $100 \quad(73 \%)$ & $64 \quad(53 \%)$ \\
\hline Willingness to take risks & $(45 \%)$ & $65 \quad(50 \%)$ \\
\hline Willingness to 'play the game' & $65 \quad(44 \%)$ & $(48 \%)$ \\
\hline $\begin{array}{l}\text { Accurately identifying the company values } \\
\qquad\left(\chi^{2} 6.833 ; \mathrm{df}=2 ; \mathrm{p}=0.033\right)\end{array}$ & $66 \quad(44 \%)$ & $(47 \%)$ \\
\hline Knowing and influencing the right people & $(39 \%)$ & $58 \quad(45 \%)$ \\
\hline Displaying entrepreneurial initiative & $69 \quad(47 \%)$ & $55 \quad(44 \%)$ \\
\hline Luck - being in the right place at the right time & $53 \quad(36 \%)$ & $56 \quad(43 \%)$ \\
\hline Educational credentials / qualifications & $45 \quad(31 \%)$ & $56 \quad(42 \%)$ \\
\hline Role models & $52 \quad(37 \%)$ & $48 \quad(40 \%)$ \\
\hline Being mentored & $32(25 \%)$ & $38 \quad(35 \%)$ \\
\hline Networks/ contacts $\quad\left(\chi^{2} 6.307 ; \mathrm{df}=2 ; \mathrm{p}=0.043\right)$ & $(20 \%)$ & $39 \quad(33 \%)$ \\
\hline Impersonal decisions made at a higher level & $(34 \%)$ & $(28 \%)$ \\
\hline Performance management and appraisal schemes & $(25 \%)$ & $28 \quad(23 \%)$ \\
\hline Off the job experiences/ interests outside work & $(21 \%)$ & $(23 \%)$ \\
\hline Internal politics & $(22 \%)$ & $(22 \%)$ \\
\hline Having a career plan & $(20 \%)$ & $(22 \%)$ \\
\hline Access to appropriate networks $\quad\left(\chi^{2} 17.248 ; \mathrm{df}=2 ; \mathrm{p}=0.001\right)$ & $(14 \%)$ & $20 \quad(20 \%)$ \\
\hline Being sponsored & $(13 \%)$ & $15 \quad(18 \%)$ \\
\hline
\end{tabular}


Table 5: Problems encountered by managers in their careers to date

\begin{tabular}{|c|c|c|}
\hline Factor & Men & Women \\
\hline Limited promotion opportunities & $88(60 \%)$ & $76(56 \%)$ \\
\hline Organisational/internal politics & $82 \quad(55 \%)$ & $75 \quad(56 \%)$ \\
\hline Absence of mentors & $67 \quad(45 \%)$ & $(52 \%)$ \\
\hline Lack of training provision & $59 \quad(40 \%)$ & $(51 \%)$ \\
\hline Lack of own career strategies & $60 \quad(41 \%)$ & $(50 \%)$ \\
\hline Lack of feedback on performance & $86 \quad(58 \%)$ & $(49 \%)$ \\
\hline Lack of career guidance & $70 \quad(47 \%)$ & $66 \quad(49 \%)$ \\
\hline Personality clash with line managers & $74 \quad(50 \%)$ & $(47 \%)$ \\
\hline Lack of confidence & $54 \quad(37 \%)$ & $(43 \%)$ \\
\hline Personal factors (e.g. being too blunt, outspoken) & $62 \quad(42 \%)$ & $(42 \%)$ \\
\hline Prejudice of colleagues & $61(41 \%)$ & $(42 \%)$ \\
\hline Lack of challenging high profile assignments & $56 \quad(38 \%)$ & $(42 \%)$ \\
\hline Conflicts between personal and work life & $62(42 \%)$ & $55 \quad(41 \%)$ \\
\hline Competition from peers & $60 \quad(41 \%)$ & $(41 \%)$ \\
\hline Double standards for evaluating performance & $68 \quad(46 \%)$ & $(41 \%)$ \\
\hline Pay inequities & $51 \quad(35 \%)$ & $(38 \%)$ \\
\hline Organisational culture & $43 \quad(29 \%)$ & $(36 \%)$ \\
\hline Lack of assertiveness & $39 \quad(26 \%)$ & $(35 \%)$ \\
\hline Lack of support from male bosses & $41 \quad(28 \%)$ & $49 \quad(36 \%)$ \\
\hline Lack of support from male colleagues $\quad\left(\chi^{2} 7.637 ; \mathrm{df}=2 ; \mathrm{p}=0.006\right)$ & $29 \quad(20 \%)$ & $46 \quad(34 \%)$ \\
\hline Hitting the glass ceiling (blocked career progress) & $51(34 \%)$ & $(30 \%)$ \\
\hline Family commitments & $46 \quad(31 \%)$ & $(31 \%)$ \\
\hline Inflexible working practices & $35 \quad(24 \%)$ & $(31 \%)$ \\
\hline Lack of significant general management and, line experience & $38 \quad(26 \%)$ & $(32 \%)$ \\
\hline Social pressures & $33 \quad(22 \%)$ & $(30 \%)$ \\
\hline$\left(\chi^{2} 6.044 ; \mathrm{df}=2 ; \mathrm{p}=0.014\right)$ & $25 \quad(17 \%)$ & $(30 \%)$ \\
\hline $\begin{array}{l}\text { Organisational attitudes towards women } \\
(\chi 231.546 ; \mathrm{df}=2 ; \mathrm{p}=0.001)\end{array}$ & $6 \quad(4 \%)$ & $38 \quad(28 \%)$ \\
\hline $\begin{array}{ll}\text { Men's club networks } & \left(\chi^{2} 33.616 ; \mathrm{df}=2 ; \mathrm{p}=0.001\right)\end{array}$ & $(3 \%)$ & $38 \quad(28 \%)$ \\
\hline Exclusion from informal networks & $27 \quad(18 \%)$ & $34 \quad(26 \%)$ \\
\hline Not being sponsored & $42 \quad(29 \%)$ & $(25 \%)$ \\
\hline Lack of support from female colleagues & $25 \quad(17 \%)$ & $(23 \%)$ \\
\hline Lack of support from female bosses & $28 \quad(19 \%)$ & $(23 \%)$ \\
\hline Inability to shift function & $39 \quad(26 \%)$ & $(22 \%)$ \\
\hline Feelings of marginalisation & $31(21 \%)$ & $27(20 \%)$ \\
\hline Lack of political awareness & $39 \quad(26 \%)$ & $25 \quad(19 \%)$ \\
\hline Prejudice of colleagues & $27 \quad(18 \%)$ & $(19 \%)$ \\
\hline Difficulty with childcare arrangements & $18 \quad(12 \%)$ & $(17 \%)$ \\
\hline Bullying / harassment & $23 \quad(16 \%)$ & $(15 \%)$ \\
\hline$\left(\chi^{2} 5.754 ; \mathrm{df}=2 ; \mathrm{p}=0.016\right)$ & $35 \quad(24 \%)$ & $(13 \%)$ \\
\hline Lack of mobility & $15 \quad(10 \%)$ & $18 \quad(13 \%)$ \\
\hline$\left(\chi^{2} \quad 10.292 ; \mathrm{df}=2 ; \mathrm{p}=0.001\right)$ & $4 \quad(3 \%)$ & $17 \quad(13 \%)$ \\
\hline Age discrimination & $15 \quad(10 \%)$ & $15 \quad(11 \%)$ \\
\hline Sexual orientation discrimination & $3 \quad(2 \%)$ & $6 \quad(5 \%)$ \\
\hline Race discrimination & $(1 \%)$ & $(2 \%)$ \\
\hline No barriers & $16 \quad(12 \%)$ & $16 \quad(13 \%)$ \\
\hline
\end{tabular}


Table 6: Managers' responses to statements made about work (percentage agreeing with the statement)

\begin{tabular}{|c|c|c|}
\hline Statement & Men & Women \\
\hline I want to be considered for promotion & $118(81 \%)$ & $92(70 \%)$ \\
\hline I lack confidence to apply for promotion & $11(8 \%)$ & $27(21 \%)$ \\
\hline I lack self confidence/esteem $\quad\left(\chi^{2} 14.133 ; \mathrm{df}=2 ; \mathrm{p}=0.001\right)$ & $19(13 \%)$ & $41(31 \%)$ \\
\hline I am accepted as a valued member of the management team & $122(82 \%)$ & $97(75 \%)$ \\
\hline I make myself visible to senior managers & $92(65 \%)$ & $91(69 \%)$ \\
\hline I receive frequent and specific feedback on my job performance & $49(33 \%)$ & $54(41 \%)$ \\
\hline I lack encouragement from my superiors & $35(24 \%)$ & $33(25 \%)$ \\
\hline I have little access to power \& challenging jobs & $22(15 \%)$ & $26(20 \%)$ \\
\hline I feel left out of important networks & $25(18 \%)$ & $25(19 \%)$ \\
\hline I find it difficult to be included in informal networks & $15(11 \%)$ & $16(14 \%)$ \\
\hline $\begin{array}{l}\text { I am given the same opportunities to grow \& develop, and to contribute to } \\
\text { the company as colleagues of the opposite sex }\end{array}$ & $119(82 \%)$ & $101(75 \%)$ \\
\hline $\begin{array}{l}\text { I am given the same level of counseling on professional career } \\
\text { advancement opportunities as colleagues of the opposite sex }\end{array}$ & $103(74 \%)$ & $95(73 \%)$ \\
\hline $\begin{array}{l}\text { My organisation is committed to policies of equal career development } \\
\left(\chi^{2} 14.318 ; \mathrm{df}=2 ; \mathrm{p}=0.001\right)\end{array}$ & $127(86 \%)$ & $94(70 \%)$ \\
\hline Informal processes of selection exist in my organisation & $88(60 \%)$ & $77(58 \%)$ \\
\hline Promotion is in the hands of one's line manager & $63(44 \%)$ & $54(41 \%)$ \\
\hline I am well thought of in my company & $115(78 \%)$ & $101(77 \%)$ \\
\hline I sometimes feel isolated at work & $46(31 \%)$ & $45(34 \%)$ \\
\hline I prefer to work for a male boss & $12(9 \%)$ & $27(21 \%)$ \\
\hline I am excluded from important decision making meetings & $31(21 \%)$ & $28(21 \%)$ \\
\hline My lack of political awareness has held me back & $27(19 \%)$ & $18(14 \%)$ \\
\hline A masculine culture exists in retailing & $52(35 \%)$ & $63(41 \%)$ \\
\hline The old boy network is still strong in most organisations & $53(37 \%)$ & $62(47 \%)$ \\
\hline $\begin{array}{l}\text { Informal social networks assist men's managerial advancement } \\
\qquad\left(\chi^{2} \quad 7.156 ; \mathrm{df}=2 ; \mathrm{p}=0.028\right)\end{array}$ & $46(33 \%)$ & $60(46 \%)$ \\
\hline $\begin{array}{l}\text { Male managers advance more rapidly than equally qualified female } \\
\text { managers in my company }\end{array}$ & $35(24 \%)$ & $41(31 \%)$ \\
\hline $\begin{array}{l}\text { There is a distinct disadvantage in being a woman and wanting a career in } \\
\text { retailing }\end{array}$ & $23(16 \%)$ & $34(26 \%)$ \\
\hline Colleagues of the opposite sex see me as a threat $\left(\chi^{2} 24.948 ; \mathrm{df}=2 ; \mathrm{p}=0.001\right)$ & $8(6 \%)$ & $28(21 \%)$ \\
\hline Men are treated more favourably by management $(\chi 28.824 ; \mathrm{df}=2 ; \mathrm{p}=0.012)$ & $14(10 \%)$ & $28(21 \%)$ \\
\hline $\begin{array}{l}\text { Men are assigned better job assignments than women } \\
\qquad\left(\chi^{2} 7.018 ; \mathrm{df}=2 ; \mathrm{p}=0.03\right)\end{array}$ & $11(7 \%)$ & $19(14 \%)$ \\
\hline $\begin{array}{l}\text { Women have to work much harder to prove themselves } \\
\qquad\left(\chi^{2} 28.806 ; \mathrm{df}=2 ; \mathrm{p}=0.001\right)\end{array}$ & $38(26 \%)$ & $76(57 \%)$ \\
\hline Men do not like to be supervised by women $\quad(\chi 241.249 ; \mathrm{df}=2 ; \mathrm{p}=0.001)$ & $24(16 \%)$ & $61(45 \%)$ \\
\hline Women still live and work in a man's world & $44(30 \%)$ & $58(43 \%)$ \\
\hline $\begin{array}{l}\text { Women are under a greater pressure at work than men } \\
\qquad\left(\chi^{2} 17.171 .318 ; \mathrm{df}=2 ; \mathrm{p}=0.001\right)\end{array}$ & $27(18 \%)$ & $50(37 \%)$ \\
\hline Men are more influential in organisations than women & $31(21 \%)$ & $36(28 \%)$ \\
\hline Women do not like to be supervised by women & $27(19 \%)$ & $19(14 \%)$ \\
\hline Women are not as ambitious as men & $8(5 \%)$ & $12(9 \%)$ \\
\hline $\begin{array}{l}\text { The qualities needed for management jobs are more likely to be found in a } \\
\text { man }\end{array}$ & $6(4 \%)$ & $10(7 \%)$ \\
\hline Men make better managers than women & $4(3 \%)$ & $4(3 \%)$ \\
\hline
\end{tabular}


